\title{
Sanguibacter antarcticus sp. nov., isolated from Antarctic sea sand
}

Correspondence
Hong Kum Lee
hklee@kopri.re.kr

\author{
Soon Gyu Hong, ${ }^{1}$ Yoo Kyung Lee, ${ }^{1}$ Joung Han Yim, ${ }^{1}$ Jongsik Chun ${ }^{2}$ \\ and Hong Kum Lee ${ }^{1}$ \\ ${ }^{1}$ Polar BioCenter, Korea Polar Research Institute, KORDI, Songdo Techno Park, Songdo-dong \\ 7-50, Yeonsu-gu, Incheon 406-840, Republic of Korea \\ ${ }^{2}$ School of Biological Sciences and Institute of Microbiology, Seoul National University, 56-1 \\ Shillim-dong, Kwanak-gu, Seoul 151-742, Republic of Korea
}

The genus Sanguibacter was established by FernándezGarayzábal et al. (1995) for isolates from blood samples of dairy cows and, at present, contains four species with validly published names: Sanguibacter suarezii, Sanguibacter keddieii and Sanguibacter inulinus, isolated from the blood of cows (Fernández-Garayzábal et al., 1995; Pascual et al., 1996), and Sanguibacter marinus, from a marine environment (Huang et al., 2005).

Strain KOPRI $21702^{\mathrm{T}}$ was isolated from a sea sand sample collected on the Weaver Peninsula $\left(62^{\circ} 13^{\prime} 45^{\prime \prime}\right.$ S $58^{\circ} 47^{\prime}$ $15^{\prime \prime} \mathrm{W}$ ) on King George Island, Antarctica. Isolation was carried out using ZoBell agar (ZoBell, 1946) supplemented with $0.4 \%$ colloidal chitin at $20{ }^{\circ} \mathrm{C}$. The isolate was maintained routinely on ZoBell agar at $20{ }^{\circ} \mathrm{C}$ and preserved as suspensions of cells in glycerol $(10 \%, \mathrm{v} / \mathrm{v})$ at $-80{ }^{\circ} \mathrm{C}$.

The 16S rRNA gene was enzymically amplified from a single colony with universal primers described by Lane (1991). The sequence was aligned manually with those of type strains of Sanguibacter species obtained from GenBank. Secondary structural information implemented in the jPHYDIT program (Jeon et al., 2005) was used for accurate alignment. Phylogenetic trees were constructed by the neighbour-joining (Saitou \& Nei, 1987), maximumparsimony (Fitch, 1971) and maximum-likelihood

The GenBank/EMBL/DDBJ accession number for the 16S rRNA gene sequence of strain KOPRI $21702^{\top}$ is EF2 11071.
(Felsenstein, 1981) methods using the program PAUP (Swofford, 2002). An evolutionary distance matrix for the neighbour-joining method was generated according to Kimura's two-parameter model (Kimura, 1980). The maximum-parsimony tree was constructed using the exhaustive search option. The confidence level of the tree topology was evaluated by bootstrap analysis (Felsenstein, 1985) using 1000 replications. An almost-complete 16S rRNA gene sequence of strain KOPRI $21702^{\mathrm{T}}$ was obtained (1468 bp). Preliminary comparisons with 16S rRNA gene sequences from GenBank revealed that the isolate showed highest sequence similarity to the type strains of the four recognized Sanguibacter species, i.e. S. keddieii ATCC $51767^{\mathrm{T}}$ (97.7\% similarity), S. suarezii ST-26 ${ }^{\mathrm{T}}(97.3 \%)$, S. inulinus $\mathrm{ST}^{-50^{\mathrm{T}}}(97.3 \%)$ and S. marinus $1-19^{\mathrm{T}}(96.8 \%)$. Phylogenetic analysis including members of Sanguibacter and related genera showed that the strain formed a distinct lineage within the genus Sanguibacter monophyletic group supported with high bootstrap values in all tree-making methods (data not presented). A reduced parsimony tree is shown in Fig. 1.

Chemotaxonomic characteristics were determined in cells grown at $30{ }^{\circ} \mathrm{C}$ on TSA medium (Difco). Isoprenoid quinones were extracted from 2-day-old cells according to the method of Minnikin et al. (1984); HPLC analysis (Collins, 1985) revealed MK-9 $\left(\mathrm{H}_{4}\right)$ as the predominant isoprenologue. Fatty acid methyl ester analysis was performed by GC (model 6890A; Hewlett-Packard) according to the Microbial Identification (MIDI) system 


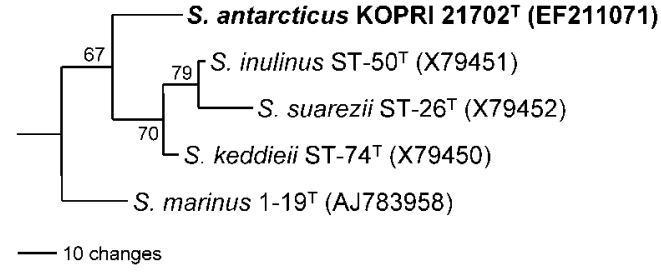

Fig. 1. Phylogenetic position of strain KOPRI $21702^{\top}$ within the genus Sanguibacter based on $16 \mathrm{~S}$ rRNA gene sequences. The tree was reconstructed by an exhaustive search with the parsimony criterion. Bootstrap support (\%) is given at nodes (only values $>50 \%$ are shown). Micrococcus luteus DSM $20030^{\top}$ was used as an outgroup (not shown).

using 1-day-old cells. The fatty acid profile consisted of anteiso- $\mathrm{C}_{15: 0} \quad(50.5 \%), \mathrm{C}_{16: 0} \quad(9.6 \%)$, anteiso- $\mathrm{C}_{13: 0}$ $(7.6 \%)$, iso- $\mathrm{C}_{16: 0}(7.5 \%)$, anteiso- $\mathrm{C}_{17: 0}(6.4 \%)$, anteiso$\mathrm{C}_{15: 1} \mathrm{~A}(4.5 \%), \mathrm{C}_{14: 0}(4.3 \%)$, iso- $\mathrm{C}_{17: 1} \mathrm{I} /$ anteiso- $\mathrm{C}_{17: 1} \mathrm{~B}$ $(2.1 \%)$, iso- $\mathrm{C}_{14: 0}(1.9 \%), \mathrm{C}_{17: 0}(1.5 \%)$ and iso- $\mathrm{C}_{15: 0}$ $(1.1 \%)$; small amounts (less than $1 \%$ ) of other fatty acids were also present. The DNA G $+\mathrm{C}$ content was $69.5 \mathrm{~mol} \%$, as determined by analysis of deoxyribonucleosides (Mesbah et al., 1989) using HPLC equipped with a C18 reversed-phase column (Supelco). The above characteristics of strain KOPRI $21702^{\mathrm{T}}$ are consistent with its assignment to the genus Sanguibacter.

The temperature range for growth was determined in a temperature-gradient incubator (TVS126MA; Advantec) using tryptic soy broth (Difco) in the range $5-50{ }^{\circ} \mathrm{C}$. Optimal growth was obtained at $23-26{ }^{\circ} \mathrm{C}$ and the maximum temperature for growth was $30{ }^{\circ} \mathrm{C}$. Growth at different $\mathrm{pH}$ (between $\mathrm{pH} 4$ and 10 at intervals of $1 \mathrm{pH}$ unit) and $\mathrm{NaCl}$ concentrations [between 0 and $10 \%(\mathrm{w} / \mathrm{v})$ at intervals of 2 or $3 \%$ ] was determined using tryptic soy broth (Difco). Growth in anaerobic conditions was examined in the anaerobic chamber with an atmosphere of $80 \%$ nitrogen, $10 \%$ carbon dioxide and $10 \%$ hydrogen at $30{ }^{\circ} \mathrm{C}$ for up to 5 days using thioglycollate medium (Sigma). Enzyme activities, assimilation and fermentation of sole carbon sources, nitrate reduction and indole production were determined using the API 20E, API 20NE and API 50CHB systems (bioMérieux). Morphological examinations of cells of strain KOPRI $21702^{\mathrm{T}}$ were performed by differential interference contrast microscopy and scanning and transmission electron microscopy of cells grown on TSA (Difco) at $30{ }^{\circ} \mathrm{C}$ for 2 days. Cellular motility was tested on motility medium $(0.3 \%$ beef extract, $1 \%$ peptone, $0.5 \% \mathrm{NaCl}, 0.4 \%$ agar). Detailed results of these experiments are given in the species description. Morphological and physiological characteristics that differentiate strain KOPRI $21702^{\mathrm{T}}$ from the other species of the genus Sanguibacter are given in Table 1.

The strain can be readily differentiated from other members of the genus Sanguibacter by its maximal growth
Table 1. Characteristics that differentiate strain KOPRI $21702^{\top}$ from related Sanguibacter species

Strains: 1 , S. antarcticus sp. nov. KOPRI $21702^{\mathrm{T}} ; 2$, S. inulinus ST- $50^{\mathrm{T}}$; 3, S. keddieii ST-74 $4^{\mathrm{T}}$; , S. marinus $1-19^{\mathrm{T}}$; 5, S. suarezii ST-26 ${ }^{\mathrm{T}}$. +, Positive; -, negative; ND, not determined; V, variable; $\mathrm{W}$, weakly positive. Data are taken from this study and from FernándezGarayzábal et al. (1995), Pascual et al. (1996) and Huang et al. (2005).

\begin{tabular}{|c|c|c|c|c|c|}
\hline Characteristic & 1 & 2 & 3 & 4 & 5 \\
\hline Growth at $35{ }^{\circ} \mathrm{C}$ on agar & - & + & + & + & + \\
\hline Nitrate reduction & + & $\mathrm{V}$ & - & + & $\mathrm{V}$ \\
\hline Gelatin hydrolysis & - & ND & + & + & - \\
\hline \multicolumn{6}{|l|}{ Acid production from: } \\
\hline$N$-Acetylglucosamine & - & + & + & - & - \\
\hline Amygdalin & - & + & + & - & $\mathrm{W}$ \\
\hline Arbutin & - & + & + & + & + \\
\hline D-Galactose & - & + & + & + & + \\
\hline Gentiobiose & + & + & + & - & + \\
\hline Gluconate & - & + & $\mathrm{V}$ & - & - \\
\hline Glycerol & - & + & + & - & + \\
\hline Inulin & - & + & - & - & - \\
\hline 5-Ketogluconate & - & + & - & - & - \\
\hline D-Lactose & - & + & + & + & + \\
\hline D-Lyxose & - & + & + & - & + \\
\hline D-Mannitol & + & $\mathrm{V}$ & - & - & - \\
\hline D-Mannose & - & + & + & + & + \\
\hline Melibiose & - & + & + & - & + \\
\hline Methyl $\alpha$-D-glucoside & - & + & + & $\mathrm{W}$ & - \\
\hline Methyl $\alpha$-D-mannoside & - & + & + & - & - \\
\hline Methyl $\beta$-D-xyloside & - & $\mathrm{V}$ & + & - & + \\
\hline D-Raffinose & - & + & + & - & V \\
\hline L-Rhamnose & - & + & + & - & + \\
\hline D-Ribose & + & + & + & - & + \\
\hline Salicin & - & + & + & + & + \\
\hline D-Sorbitol & - & - & + & - & - \\
\hline Turanose & + & + & + & - & + \\
\hline
\end{tabular}

temperature, the ability to reduce nitrate, the inability to hydrolyse gelatin and acid production from various carbon sources, as presented in Table 1. Therefore, it is concluded that strain KOPRI $21702^{\mathrm{T}}$ should be assigned to the genus Sanguibacter as the type strain of a novel species. The name Sanguibacter antarcticus sp. nov. is proposed for the Antarctic isolate.

\section{Description of Sanguibacter antarcticus sp. nov.}

Sanguibacter antarcticus (an.tarc'ti.cus. L. masc. adj. antarcticus southern, pertaining to the Antarctic, the geographical origin of the type strain).

Gram-positive, catalase-positive, oxidase-negative, facultatively anaerobic and mesophilic. Cells are irregular and motile rods $(0.6-45 \times 0.4-0.6 \mu \mathrm{m})$ with sparse peritrichous flagella. Colonies are yellow, circular and convex with entire edges. Diffusible pigments are not produced. Growth occurs under aerobic and anaerobic conditions. Growth occurs at pH 4-9 (optimum $\mathrm{pH}$ 5-6) and with 0-7\% $\mathrm{NaCl}$ 
(optimum 2-5\%). Grows at $4-30{ }^{\circ} \mathrm{C}$ (optimum $23-26{ }^{\circ} \mathrm{C}$ ). Acid is produced from L-arabinose, cellobiose, aesculin, fructose, gentiobiose, glucose, glycogen, maltose, mannitol, ribose, starch, sucrose, trehalose, turanose and D-xylose (API 50CHB). Acid is not produced from $\mathrm{N}$-acetylglucosamine, adonitol, amygdalin, D-arabinose, D-arabitol, Larabitol, arbutin, dulcitol, erythritol, D-fucose, L-fucose, galactose, gluconate, glycerol, inositol, inulin, 2-ketogluconate, 5-ketogluconate, lactose, D-lyxose, mannose, melibiose, melezitose, methyl $\alpha$-D-glucoside, methyl $\alpha$-Dmannoside, methyl $\beta$-D-xyloside, raffinose, rhamnose, salicin, sorbitol, sorbose, D-tagatose, xylitol or L-xylose (API 50CHB). Citrate is utilized and acetoin is produced weakly, but negative for arginine dihydrolase, cytochrome oxidase, $\beta$-galactosidase, gelatinase, $\mathrm{H}_{2} \mathrm{~S}$ production, indole production, lysine decarboxylase, ornithine decarboxylase, tryptophan deaminase and urease (API 20E). Nitrate is reduced to nitrite and nitrogen (API 20NE). Major isoprenoid quinone is $\mathrm{MK}-9\left(\mathrm{H}_{4}\right)$. Predominant cellular fatty acids are anteiso- $\mathrm{C}_{15: 0}(50.5 \%), \mathrm{C}_{16: 0} \quad(9.6 \%)$, anteiso- $\mathrm{C}_{13: 0}(7.6 \%)$ and iso- $\mathrm{C}_{16: 0}(7.5 \%)$.

The type strain is KOPRI $21702^{\mathrm{T}}\left(=\mathrm{KCTC} 13143^{\mathrm{T}}=\mathrm{JCM}\right.$ $14623^{\mathrm{T}}=\mathrm{DSM} 18966^{\mathrm{T}}$ ), isolated from a sea sand sample from King George Island, Antarctica. The genomic DNA $\mathrm{G}+\mathrm{C}$ content of the type strain is $69.5 \mathrm{~mol} \%$.

\section{Acknowledgements}

We are grateful to Dr J. P. Euzéby for help with nomenclature. This work was supported by KOPRI grant (PE06050), Republic of Korea.

\section{References}

Collins, M. D. (1985). Analysis of isoprenoid quinones. Methods Microbiol 18, 329-366.

Felsenstein, J. (1981). Evolutionary trees from DNA sequences: a maximum likelihood approach. J Mol Evol 17, 368-376.
Felsenstein, J. (1985). Confidence limits on phylogenies: an approach using the bootstrap. Evolution 39, 783-791.

Fernández-Garayzábal, J. F., Dominguez, L., Pascual, C., Jones, D. \& Collins, M. D. (1995). Phenotypic and phylogenetic characterization of some unknown coryneform bacteria isolated from bovine blood and milk: description of Sanguibacter gen. nov. Lett Appl Microbiol 20, 69-75.

Fitch, W. M. (1971). Toward defining the course of evolution: minimum change for a specific tree topology. Syst Zool 20, 406-416.

Huang, Y., Dai, X., He, L., Wang, Y.-N., Wang, B.-J., Liu, Z. \& Liu, S.-J. (2005). Sanguibacter marinus sp. nov., isolated from coastal sediment. Int J Syst Evol Microbiol 55, 1755-1758.

Jeon, Y. S., Chung, H., Park, S., Hur, I., Lee, J. H. \& Chun, J. (2005). jPHYDIT: a JAVA-based integrated environment for molecular phylogeny of ribosomal RNA sequences. Bioinformatics 21, 3171-3173.

Kimura, M. (1980). A simple method for estimating evolutionary rates of base substitutions through comparative studies of nucleotide sequences. J Mol Evol 16, 111-120.

Lane, D. J. (1991). 16S/23S rRNA sequencing. In Nucleic Acid Techniques in Bacterial Systematics, pp. 115-175. Edited by E. Stackebrandt \& M. Goodfellow. New York: John Wiley.

Mesbah, M., Premachandran, U. \& Whitman, W. B. (1989). Precise measurement of the $\mathrm{G}+\mathrm{C}$ content of deoxyribonucleic acid by highperformance liquid chromatography. Int J Syst Bacteriol 39, 159-167.

Minnikin, D. E., O'Donnell, A. G., Goodfellow, M., Alderson, G., Athalye, M., Schaal, A. \& Parlett, J. H. (1984). An integrated procedure for the extraction of bacterial isoprenoid quinones and polar lipids. J Microbiol Methods 2, 233-241.

Pascual, C., Collins, M. D., Grimont, P. A. D., Dominguez, L. \& Fernandez-Garayzabal, J. F. (1996). Sanguibacter inulinus sp. nov. Int J Syst Bacteriol 46, 811-813.

Saitou, N. \& Nei, M. (1987). The neighbor-joining method: a new method for reconstructing phylogenetic trees. Mol Biol Evol 4, 406-425.

Swofford, D. L. (2002). PAUP*: Phylogenetic analysis using parsimony ( ${ }^{*}$ and other methods), version 4. Sunderland, MA: Sinauer Associates.

ZoBell, C. E. (1946). Marine Microbiology: a Monograph on Hydrobacteriology. Waltham, MA: Chronica Botanica. 